\title{
Integrated nutrient management practices on growth and yield of field pea (Pisum sativum L.) under mid hill condition
}

\author{
DHIMAN MUKHERJEE \\ Directorate of Research, Bidhan Chandra Krishi Viswavidyalaya, KALYANI (W.B.) INDIA
}

\begin{abstract}
A field experiment was conducted during two consecutive Rabi seasons of 2011-12 and 2012-13, to study the effect of various source of nutrient in combination with bio-fertilizers and PSB on growth and yield of field pea at Regional Research Station (Hill Zone), Kalimpong. The experiment was laid out in Randomized Block Design with three replications. The experiment comprised of thirteen treatment combinations. Results indicated that the combined application of $75 \% \mathrm{RDF}+25 \% \mathrm{~N}$ through vermicompost (@1.90 tonn/ha) and seed inoculation with Rhizobium + PSB improved all the growth, yield attributes and yields of field pea. Plant height, number of leaves/plant, number of branches/plant, number of nodules/plant, fresh and dry weight of nodule/ plant were significantly varied with various treatments and was maximum with full dose of RDF along with Rhizobium and PSB combination and showed parity with 75\% RDF + vermicompost + Rhizobium + PSB . Number of seeds/pod, number of pods/ plant and other yield attributing characters significantly more with 75\% RDF + vermicompost + Rhizobium + PSB. Maximum grain yield was registered with full dose of RDF along with Rhizobium and PSB $(26.74 \mathrm{q} / \mathrm{ha})$ and remained at par with $75 \%$ RDF + vermicompost + Rhizobium + PSB (25.08 q/ha). Increase in grain yield in the tune of 135.2 and $120.7 \%$ more with RDF + Rhizobium $+\mathrm{PSB}$ and $75 \% \mathrm{RDF}+$ vermicompost + Rhizobium $+\mathrm{PSB}$, respectively over control. Economics revealed that highest benefit cost ratio was registered with 75\% RDF + vermicompost + Rhizobium + PSB (2.62) and was closely followed by full dose of RDF along with Rhizobium and PSB (2.50). Therefore, it can be suggested that to obtain the maximum grain yield and net profit from field pea, seed should be inoculated with Rhizobium + PSB in addition to $75 \% \mathrm{RDF}+25 \%$ nitrogen through vermicompost.
\end{abstract}

Key Words : Field pea, PSB, Rhizobium, Vermicompost, Yield

View Point Article : Mukherjee, Dhiman (2016). Integrated nutrient management practices on growth and yield of field pea (Pisum sativum L.) under mid hill condition. Internat. J. agric. Sci., 12 (2) : 309-313, DOI:10.15740/HAS/IJAS/12.2/309-313.

Article History : Received : 20.02.2016; Revised : 19.03.2016; Accepted : 15.05.2016 